\title{
PENGARUH MODEL PEMBELAJARAN INQUIRY TRAINING TERHADAP HASIL BELAJAR SISWA PADA MATERI POKOK SUHU DAN KALOR DIKELASX SEMESTER II SMANEGERI1 SIIMAKUTASARIBUDOLOK T.P 2014/2015
}

\author{
Iramaya Fridayanti Sinaga dan Nurdin Siregar \\ Jurusan Fisika FMIPA Universitas Negeri Medan \\ iramayasinaga23@gmail.com
}

\begin{abstract}
ABSTRAK
Penelitian ini bertujuan untuk mengetahui pengaruh model pembelajaran inquiry training terhadap hasil belajar siswa kelas X semester II pada materi pokok suhu dan kalor di SMA Negeri 1 Silimakuta Saribudolok T.P 2014/2015. Jenis penelitian ini adalah quasi eksperiment. Populasi dalam penelitian adalah seluruh siswa kelas X Semester II. Pengambilan sampel dilakukan dengan cara cluster random sampling dengan mengambil kelas yang akan diberikan perlakuan. Kelas X-1 sebagai kelas eksperimen dan kelas X-3 sebagai kelas kontrol. Instrumen yang digunakan dalam penelitian ini berupa tes hasil belajar untuk mengetahui hasil belajar siswa dan lembar observasi untuk mengetahui aktivitas belajar siswa. Berdasarkan hasil uji hipotesis menggunakan uji t diperoleh bahwa ada pengaruh penggunaan model pembelajaran inquiry training terhadap hasil belajar siswa pada materi pokok suhu dan kalor.
\end{abstract}

Kata kunci :inquiry training, hasil belajar

\begin{abstract}
$A B S T R A C T$
This study aimed to determine the effect of inquiry training model on learning outcomesof studentsin the subject matterof heat and temperature in SMA Negeri 1 Silimakuta Saribudolok T.P 2014/2015. This research is a quasi experimental with two group pretest-posttest design. The population is the entire second semester of tenth grade students consisting. Sampling was done by cluster random sampling that is class $X_{1}$ as the experimental class and class $X_{3}$ as the control class. The instrument used is the achievement test as form of test results to learn and observation sheet to determine the activity of student learning activities. Based on data analysis and hypothesis testing showed that there is effect of inquiry training model on learning outcomes of student in the subject matter of heat and temperature.
\end{abstract}

Keywords : inquiry training, learning outcomes.

\section{PENDAHULUAN}

Pendidikan memegang peranan penting dalam pengembangan semua potensi, kecakapan, serta karakteristik sumber daya manusia kearah positif, baik bagi dirinya maupun bagi lingkungannya. Pendidikan merupakan proses mendidik, yaitu suatu proses dalam rangka mempengaruhi peserta didik agar mampu menyesuaikan diri sebaik mungkin dengan lingkungannya, sehingga akan menimbulkan perubahan dalam dirinya. Pendidikan yang banyak dan semakin tinggi akan membuat seseorang memperoleh kehidupan yang semakin baik.

Permasalahan besar dalam proses pembelajaran saat ini adalah kurangnya usaha pengembangan berpikir yang menuntun siswa untuk menguasai konsep. Proses ini lebih banyak mendorong siswa agar dapat 
menguasai materi pelajaran supaya dapat menjawab semua soal ujian yang diberikan. Kenyataan menunjukkan siswa kurang aktif dalam kegiatan belajar. Siswa lebih banyak mendengar dan menulis apa yang diterangkan oleh guru di papan tulis. Berdasarkan hasil penelitian dari pusat kurikulum, ternyata metode ceramah adalah metode yang paling sering digunakan. Hal ini menyebabkan isi mata pelajaran fisika dianggap sebagai hafalan, sehingga siswa tidak menguasai konsep (Sirait dan Sahyar, $2013: 3)$.

Fisika sebagai cabang Ilmu Pengetahuan Alam (IPA) merupakan objek mata pelajaran yang menarik dan lebih banyak memerlukan pemahaman daripada penghafalan. Trisno $\mathrm{dkk}$ (2014:14) mengatakan bahwa ada kesan yang kuat menyatakan bahwa pelajaran fisika merupakan pelajaran yang sulit untuk dipahami dan kurang menarik. Salah satu penyebabnya adalah kurangnya kesempatan siswa untuk mempelajari, mengamati dan menemukan sendiri. Selain itu ada beberapa faktor yang menyebabkan rendahnya hasil belajar fisika diantaranya proses pembelajaran yang ditemukan secara umum lebih menekankan pada tuntutan pencapaian kurikulum dan sebagian guru yang belum menciptakan suasana pembelajaran yang menarik dan menyenangkan, sehingga siswa kurang termotivasi dan merasa terbebani dalam belajar fisika. Berdasarkan hasil wawancara dengan guru mata pelajaran fisika di SMA Negeri 1 Silimakuta Saribudolok, nilai rata-rata ulangan harian siswa untuk mata pelajaran fisika di kelas X hanya 42,85 $\%$ atau 60 orang dari 140 siswa yang memperoleh nilai diatas KKM. Siswa menyatakan bahwa pelajaran fisika adalah pelajaran yang sulit dipahami dan kurang menarik, dengan alasan bahwa pelajaran fisika itu tidak terlepas dari rumus-rumus yang harus dihafal Berdasarkan kenyataan diatas, perlu diterapkan suatu model pembelajaran yang akan mengubah cara belajar siswa, dimana siswa akan bertindak lebih aktif dalam proses pembelajaran. Mengingat fisika merupakan suatu pembelajaran yang pada dasarnya adalah suatu proses yang diarahkan pada gejala alam yang terjadi. Adapun model pembelajaran yang ditawarkan dan yang sesuai untuk mengubah cara belajar siswa yaitu dengan menggunakan model pembelajaran inquiry training.

Penggunaan model pembelajaran inquiry training dirancang untuk membawa siswa langsung kedalam proses-proses ilmiah melalui latihan. Model ini membantu siswa untuk mengembangkan disiplin dan mengembangkan keterampilan intelektual yang diperlukan untuk mengajukan pertanyaan dan menemukan jawabannya. Hasil penelitian yang dilakukan oleh harahap, diperoleh bahwa ada pengaruh yang signifikan terhadap hasil belajar siswa dengan menggunakan model pembelajaran inquiry training. Begitu juga dengan hasil penelitian yang dilakukan oleh Hutapea yang menyatakan bahwa penggunaan model pembelajaran inquiry training memiliki hasil belajar yang lebih tinggi dibandingkan dengan model pembelajaran konvensional. Model ini membantu siswa untuk mengembangkan disiplin dan mengembangkan keterampilan intelektual yang diperlukan untuk mengajukan pertanyaan dan menemukan jawabannya. Melalui model pembelajaran ini siswa diharapkan aktif mengajukan pertanyaan mengapa sesuatu terjadi kemudian mencari dan mengumpulkan serta memproses data secara logis untuk selanjutnya mengembangkan strategi intelektual yang dapat digunakan untuk menemukan jawaban atas pertanyaan tersebut

Berdasarkan latar belakang diatas, maka dilakukan penelitian 
dengan tujuan untuk mengetahui pengaruh model pembelajaran inquiry training terhadap hasil belajar siswa pada materi pokok suhu dan kalor di kelas $\mathrm{X}$ semester II SMA Negeri 1 Silimakuta Saribudolok.

\section{METODE PENELITIAN}

Populasi dalam penelitian ini adalah seluruh siswa kelas X SMA Negeri 1 Silimakuta saribudolok T.P 2014/2015 yang terdiri dari 8 kelas. Jenis penelitian ini adalah quasi experiment. Sampel penelitian dipilih dengan cluster random sampling,kelas X-1 sebagai kelas eksperimen yang menerapkan model inquiry training dan kelas X-3 sebagai kelas kontrol yang menerapkan pembelajaran konvensional. Variabel dalam penelitian meliputi model inquiry training dan pembelajaran konvensional sebagai variabel bebas dan hasil belajar siswa pada materi suhu dan kalor merupakan variabel terikat. Desain penelitian yang digunakan adalah two group pretestposttest design seperti pada tabel dibawah ini

Tabel 1.two group pretest-postest design. (Arikunto, 2012)

\begin{tabular}{|l|l|l|r|l|}
\hline No & Kelas & $\begin{array}{l}\text { Tes } \\
\text { awal }\end{array}$ & $\begin{array}{l}\text { Perlak } \\
\text { uan }\end{array}$ & $\begin{array}{l}\text { Tes } \\
\text { Akh } \\
\text { ir }\end{array}$ \\
\hline 1. & $\begin{array}{l}\text { Kelas } \\
\text { Eksperi } \\
\text { men }\end{array}$ & $\mathrm{Y}_{1}$ & $\mathrm{X}_{1}$ & $\mathrm{Y}_{2}$ \\
\hline 2. & $\begin{array}{l}\text { Kelas } \\
\text { Kontrol }\end{array}$ & $\mathrm{Y}_{1}$ & $\mathrm{X}_{2}$ & $\mathrm{Y}_{2}$ \\
\hline
\end{tabular}

Keterangan :

$\mathrm{X}_{1}$ : Pembelajaran dengan menggunakan model pembelajaran inquiry training

$\mathrm{X}_{2} \quad$ : $\quad$ Pembelajaran dengan menggunakan model pembelajaran konvensional

$\mathrm{Y}_{1}$ : Pretes diberikan pada kelas eksperimen dan kelas kontrol sebelum perlakuan.
$\mathrm{Y}_{2}$ : Postes diberikan setelah perlakuan pada kelas eksperimen dan kelas kontrol

Metode pengumpulan data meliputi wawancara kepada salah satu guru di sekolah yang bersangkutan yang berisi 10 pertanyaan dan diajukan kepada guru untuk mengetahui bagaimana guru melaksanakan proses pembelajaran di kelas, menggunakan lembar observasi aktivitas yang digunakan untuk mengetahui aktivitas siswa selama kegiatan belajar mengajar yang dibantu oleh dua orang observer dan tes hasil belajar berjumlah 15 soal.

Teknik analisis yang digunakan untuk menentukan pengaruh model inquiry training terhadap hasil belajar siswa adalah melakukan uji hipotesis dengan menggunakan uji beda (uji $t$ ) dengan syarat data harus berdistribusi normal dan bersifat homogen (Sudjana, 2005). Teknik analisis ini dilakukan pada data tes hasil belajar yang diperoleh yaitu data pretes dan postes.

Apabila hasil pretes kedua kelas memiliki kesamaan rata-rata, berarti kemampuan awal kelas eksperimen sama dengan kemampuan awal siswa pada kelas kontrol. Apabila hasil postes kelas eksperimen yang menerapkan model inquiry training lebih tinggi dari kelas kontrol dengan pembelajaran konvensional, berarti ada perbedaan hasil belajar yang signifikan akibat penerapan model inquiry training, sehingga dapat disimpulkan bahwa model ini ada pengaruhnya terhadap hasil belajar siswa.

\section{HASIL DAN PEMBAHASAN Hasil Penelitian}

Dibawah ini adalah tabel-tabel dari nilai rata-rata, uji normalitas, uji homogenitas dari pretes dan postes kedua kelas secara ringkas. 
Tabel 1. Nilai Rata-Rata Pretes dan Postes Kedua Kelas

\begin{tabular}{|c|c|c|}
\hline \multirow{2}{*}{ Kelas } & \multicolumn{2}{|c|}{ Rata-Rata } \\
\cline { 2 - 3 } & Pretes & Postes \\
\hline Eksperimen & 36,86 & 72,35 \\
\hline Kontrol & 33,89 & 62,59 \\
\hline
\end{tabular}

Tabel diatas menunjukkan bahwa nilai rata-rata pretes pada kedua kelas hampir sama, sedangkan setelah diberikan perlakuan diperoleh bahwa nilai rata-rata postes kelas eksperimen lebih tinggi dibandingkan di kelas kontrol. Hasil diatas tampak perbedaan hasil belajar sebesar 9,76 antara kelas eksperimen dan kelas kontrol.

Tabel 2. Perhitungan Uji Normalitas Pretes dan Postes

\begin{tabular}{|l|l|c|c|c|}
\hline Data & Kelas & Lhitung & Ltabel & $\begin{array}{c}\text { Kesimpul } \\
\text { an }\end{array}$ \\
\hline $\begin{array}{l}\text { Pret } \\
\text { es }\end{array}$ & $\begin{array}{l}\text { Eksperim } \\
\text { en }\end{array}$ & 0,1406 & 0,1519 & Normal \\
\cline { 2 - 5 } & Kontrol & 0,1310 & 0,1477 & Normal \\
\hline $\begin{array}{l}\text { Post } \\
\text { es }\end{array}$ & $\begin{array}{l}\text { Eksperim } \\
\text { en }\end{array}$ & 0,1362 & 0,1519 & Normal \\
\cline { 2 - 5 } & Kontrol & 0,1342 & 0,1477 & Normal \\
\hline
\end{tabular}

Tabel di atas menunjukan bahwa data pretes dan data postes berdistribusi normal. Hal ini terlihat dari harga Lhitung tidak melebihi $\mathrm{L}_{\text {tabel }}$ (Lhitung $<\mathrm{L}_{\text {tabel }}$ ) yang mengindikasikan bahwa data berdistribusi normal

Tabel 3. Perhitungan Uji Homogenitas Pretes dan Postes

\begin{tabular}{|l|l|c|c|c|}
\hline Data & Kelas & $\begin{array}{c}\mathrm{F}_{\text {hitun }} \\
\mathrm{g}\end{array}$ & $\mathrm{F}_{\text {tabel }}$ & $\begin{array}{c}\text { Kesimpula } \\
\mathrm{n}\end{array}$ \\
\hline $\begin{array}{l}\text { Pret } \\
\text { es }\end{array}$ & $\begin{array}{l}\text { Eksperim } \\
\text { en }\end{array}$ & \begin{tabular}{c}
1,38 \\
\cline { 2 - 5 }
\end{tabular} & $\begin{array}{c}1,83 \\
8\end{array}$ & Homomogen \\
\cline { 2 - 5 } $\begin{array}{l}\text { Post } \\
\text { es }\end{array}$ & $\begin{array}{l}\text { Eksperim } \\
\text { en }\end{array}$ & $\begin{array}{c}1,31 \\
3\end{array}$ & $\begin{array}{c}1,88 \\
0\end{array}$ & Homogen \\
\cline { 2 - 4 } & Kontrol & & \\
\hline
\end{tabular}

Dari tabel 4.4 diketahui bahwa sampel yang berupa kelas eksperimen dan kelas kontrol berasal dari populasi yang homogen. Hal ini terlihat dari harga $\mathrm{F}_{\text {hitung }}$ tidak melebihi $\mathrm{F}_{\text {tabel }}$ ( $\mathrm{F}_{\text {hitung }}<\mathrm{F}_{\text {tabel }}$ ) yang mengindikasikan bahwa sampel berasal dari populasi yang homogen.

Tabel 4. Perhitungan Uji Hipotesis

\begin{tabular}{|c|c|c|c|}
\hline $\begin{array}{c}\text { Uji } \\
\text { Hipote } \\
\text { sis }\end{array}$ & thitung & ttabel & Kesimpulan \\
\hline $\begin{array}{c}\text { Uji t } \\
\text { dua } \\
\text { pihak }\end{array}$ & $\begin{array}{c}1,14 \\
2\end{array}$ & $\begin{array}{c}1,99 \\
7\end{array}$ & $\begin{array}{c}\mathrm{H}_{0} \text { diterima } \\
\text { (Kemampuan awal } \\
\text { kedua kelas sama) }\end{array}$ \\
\hline $\begin{array}{c}\text { Uji t } \\
\text { satu } \\
\text { pihak }\end{array}$ & $\begin{array}{c}3,88 \\
\mathrm{H}_{\mathrm{a}} \text { diterima (Ada } \\
\text { pengaruh model } \\
\text { pembelajaran } \\
\text { inquiry training) }\end{array}$ \\
\hline
\end{tabular}

Hasil uji $t$ dua pihak dengan menggunakan data pretes diperoleh harga $t_{\text {hitung }}<$ ttabel $_{\text {yaitu }} 1,142<1,997$, berarti $\mathrm{H}_{0}$ diterima yaitu kemampuan awal siswa pada kelas eksperimen sama dengan kemampuan awal siswa pada kelas kontrol. Untuk uji t satu pihak yang menggunakan data postes diperoleh bahwa thitung $>$ tabel yaitu $3,889>1,669$ pada taraf signifikansi 0,05 berada pada dk 60 dan dk 120 . Dapat diambil kesimpulan bahwa hipotesis $\mathrm{H}_{\mathrm{a}}$ diterima yaitu ada pengaruh model pembelajaran inquiry training terhadap hasil belajar siswa pada materi pokok suhu dan kalor di kelas X semester II SMA Negeri 1 Silimakuta Saribudolok T.P 2014/2015.

Selain mengukur hasil belajar siswa selama mengikuti proses pembelajaran, aktivitas juga diamati oleh dua orang observer dengan menggunakan lembar observasi aktivitas. Proses pengamatan aktivitas siswa dilakukan sebanyak empat kali pertemuan, pengamatan aktivitas ini dilakukan setelah melakukan pretes. Observasi aktivitas ini dilakukan di kelas eksperimen yang sesuai dengan penerapan model pembelajaran yang digunakan. Aspek aktivitas yang dinilai adalah menyajikan pertanyaan atau masalah, membuat hipotesis, melakukan percobaan, menganalisis data, serta membuat kesimpulan. 
Rata-rata aktivitas siswa kelas eksperimen ditunjukkan pada Gambar dibawah ini.

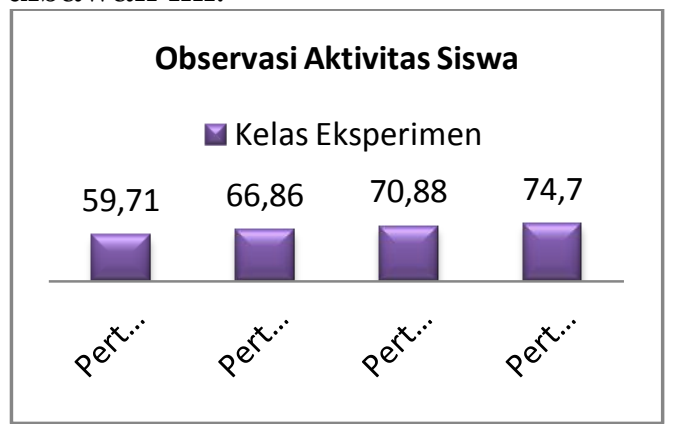

Gambar 1. Diagram Batang Aktivitas

Aktivitas siswa kelas eksperimen meningkat di setiap pertemuan. Kelas kontrol tidak memiliki penilaian aktivitas karena aktivitas pada kelas kontrol tidak cocok dengan kelima aspek penilaian aktivitas tersebut. Hal ini disebabkan karena pada kelas kontrol, guru yang lebih berperan aktif daripada siswa. Siswa hanya mendengarkan, mencatat dan mengerjakan soal yang diberikan oleh guru atau dengan kata lain pembelajaran bersifat teacher centered.

\section{Pembahasan}

Hasil penelitian menunjukkan bahwa ada pengaruh yang signifikan menggunakan model pembelajaran inquiry training terhadap hasil belajar siswa pada materi pokok suhu dan kalor dikelas X semester II SMA Negeri 1 Silimakuta Saribudolok T.P 2014/2015. Hal ini diperkuat dengan perolehan nilai rata-rata pretes siswa dikelas eksperimen sebesar 36,86 nilai rata-rata postes sebesar 72,35 Sedangkan di kelas kontrol diperoleh nilai rata-rata pretes siswa sebesar 33,89 dan nilai rata-rata postes sebesar 62,59 .

Hal ini didukung karena model pembelajaran inquiry training mengarahkan siswa untuk lebih aktif dalam belajar, karena dengan model ini maka pengetahuan dan ketrampilan yang diperoleh oleh siswa diharapkan bukan hasil mengingat seperangkat fakta-fakta, tetapi hasil dari menemukan sendiri.
Modelpembelajaran ini juga membuat siswa dapat bekerja sama dan memberikan masukan-masukan pada siswa yang lain sehingga siswa yang kurang mampu menjadi lebih termotivasi untuk mempelajari materi yang kurang dimengerti.

Awal dari tahap ini peneliti memberikan penjelasan kepada siswa tujuan yang harus dicapai baik tujuan yang berhubungan dengan penguasaan materi maupun tujuan yang berhubungan dengan proses pembelajaran serta memotivasi siswa agar lebih aktif dalam belajar. Sulit bagi siswa untuk melaksanakan suatu tugas dengan baik apabila belum mengetahui jelas tentang apa dan mengapa melakukan suatu kegiatan atau apabila tuntutan keberhasilan belum diberitahukan secara terbuka

Pada tahap kedua, peneliti mengarahkan siswa untuk bekerja secara kelompok, dengan membagikan kelompok yang terdiri dari 5-6 orang dan berjumlah sebanyak 6 kelompok. Kemudian peneliti membagikan LKS dan membagikan seperangkat alat percobaan untuk masing-masing kelompok. Peneliti terlebih dahulu menjelaskan percobaan sebelum siswa melakukan kegiatan tersebut agar siswa lebih paham mengerjakan LKS dan guru mengawasi siswa dalam pengerjaannya.

Siswa kemudian mengolah dan menyimpulkan hasil dari percobaan kemudian mempresentasikannya. Pada saat presentasi inilah siswa dituntut untuk dapat bekerjasama dan memberikan masukan-masukan pada siswa lain sehingga siswa yang kurang mampu menjadi lebih termotivasi untuk mempelajari materi yang kurang dimengerti.

Hal ini juga berkaitan dengan hasil penelitian sebelumnya yang dikutip dari jurnal nasional milik Ratni Sirait dan Sahyar (2013) yang menyatakan bahwa hasil belajar kelas eksperimen lebih tinggi dengan menggunakan model pembelajaran 
inquiry training dibandingkan kelas kontrol yang menggunakan model pembelajaran konvensional. Hal ini terjadi karena pada kelas kontrol yang diajarkan dengan menggunakan model pembelajaran konvensional, menuntut guru yang lebih aktif daripada siswa sehingga siswa lebih banyak diam dan mendengar.

Hal yang sama juga dapat dilihat dari penelitian sebelumnya yang dikutip dari jurnal pendidikan fisika tadulako milik Trisno dkk yang menyatakan bahwa model pembelajaran inquiry training yang menuntut siswa lebih aktif dalam tahap pembelajarannya, sedangkan pada kelas kontrol menggunakan model pembelajaran konvensional yang identik dengan metode ceramah sehingga siswa lebih pasif dan guru yang lebih aktif.

Hasil pengamatan yang dilakukan oleh observer diperoleh bahwa aktivitas siswa mengalami peningkatan yang positif. Hal ini sesuai dengan penelitian terdahulu milik hakim dkk yang menyatakan aktivitas pada model pembelajaran inquiry training membuat siswa bersifat lebih aktif dn mampu membuka pola pikir untuk memecahkan suatu penyelidikan yang dilakukan.

Setelah dilakukan analisis maka diperoleh pada pertemuan I rata-rata aktivitas siswa kelas eksperimen sebesar 59,71. Hal ini terjadi karena siswa belum terbiasa mengikuti pembelajaran dengan menggunakan model pembelajaran inquiry training sehingga instruksi dan motivasi yang diberikan oleh peneliti kurang dimengerti oleh beberapa orang siswa. Oleh karena itu, peneliti harus mampu memberikan instruksi dan arahan kepada siswa sehingga siswa paham dan termotivasi dalam mengikuti proses pembelajaran, contohnya seperti mengerjakan LKS. Pada pertemuan II terjadi peningkatan menjadi 66,86 . Hal ini terjadi karena siswa sudah mulai termotivasi mengikuti proses pembelajaran dan paham akan tugas serta tanggung jawab dalam pembelajaran. Pada pertemuan III dan pertemuan IV juga rata-rata aktivitas siswa semakin meningkat yaitu menjadi 70,88 dan 74,70 .

Hal ini karena siswa sudah memahami langkah-langkah yang diberikan oleh peneliti dan siswa semakin tertarik oleh kejadian nyata yang mereka alami dengan adanya praktikum., mereka tidak hanya sekedar mengetahui teori dari pelajaran atau penjelasan dari peneliti akan tetapi mereka dapat membuktikannya langsung secara praktek.

Hasil pengamatan diperoleh ratarata aktivitas siswa sebesar 68,03 termasuk ke dalam kategori aktif. Nilai aktivitas dapat dilihat pada lampiran dan secara keseluruhan aktivitas siswa dalam proses pembelajaran selama empat pertemuan dikategorikan aktif.

Dengan demikian berdasarkan hasil penelitian dan pengujian hipotesis terlihat bahwa rata-rata hasil belajar siswa pada kelas eksperimen lebih tinggi dibandingkan rata-rata hasil belajar siswa pada kelas kontrol, berarti hasil belajar dengan menggunakan model pembelajaran inquiry training lebih baik daripada model pembelajaran konvensional. Sehingga dapat disimpulkan bahwa ada pengaruh model pembelajaran inquiry training terhadap hasil belajar siswa pada materi pokok suhu dan kalor di kelas $\mathrm{X}$ semester II SMA Negeri 1 Silimakuta T.P.2014/2015

Meskipun model pembelajaran inquiry training dapat meningkatkan hasil belajar dan aktivitas siswa yang lebih baik dibanding pembelajaran konvensional, masih terdapat beberapa kendala dalam melaksanakan pembelajaran, yaitu ketika siswa melaksanakan diskusi kelompok masih terdapat siswa yang kurang aktif dan terlihat juga pada saat dituntut untuk mengajukan hipotesis dalam pengumpulan data verifikasi dan 
eksperimentasi masih ada siswa yang memilih duduk diam dan menunggu hasil hasil yang diperoleh oleh temannya daripada bergabung membantu temannya untuk memperoleh data tersebut, hal ini dikarenakan kebiasaan siswa yang belum terbiasa dalam bekerjasama dalam belajar

\section{KESIMPULAN DAN SARAN \\ Kesimpulan}

Berdasarkan hasil penelitian yang diperoleh dari hasil analisa data dan pengujian hipotesis maka dapat disimpulkan bahwa ada pengaruh model pembelajaran inquiry training terhadap hasil belajar siswa pada materi pokok suhu dan kalor di kelas $\mathrm{X}$ semester II SMA Negeri 1 Silimakuta Saribudolok T.P 2014/2015. Dimana diperoleh nilai postes dikelas eksperimen yaitu 72,35 dan dikelas kontrol yaitu 62,59. Rata-rata aktivitas dari pertemuan I sampai pertemuan IV pada kelas eksperimen adalah sebesar 68,03 yang termasuk kedalam kategori aktif.

\section{Saran}

Berdasarkan penelitian yang telah dilakukan maka beberapa hal yang disarankan untuk peneliti lebih lanjut yaitu pada saat proses pembelajaran berlangsung sebaiknya menambahkan beberapa observer untuk membantu siswa agar pembelajaran lebih terarah dan mampu mengawasi serta mengamati siswa dalam mengumpulkan data verifikasi dan eksperimentasi, serta selama proses pembelajaran berlangsung sebaiknya lebih memperhatikan efisiensi waktu di setiap tahap model pembelajaran inquiry training, agar pelaksanaan pembelajaran untuk setiap tahapannya dapat dipergunakan dengan sesuai.

\section{DAFTAR PUSTAKA}

Derlina, dan Hasibuan, T.B., Pengaruh Model Pembelajaran inquiry training Terhadap Hasil Belajar Siswa di Kelas X Semester II SMA Negeri 1 Percut Sei Tuan T.P.2013/2014, Jurnal inpafi 2: 3844

Hakim, A., Nasution, H., dan Derlina, (2012), Perbedaan Hasil Belajar Siswa Yang Dibelajarkan Dengan Model Pembelajaran Inquiry Training dan Konvensional Pada Materi Pokok Gaya dan Hukum Newton Di Kelas VIII SMP Negeri 17 Medan, Jurnal Online Pendidikan Fisika1: 8-16

Harahap, F., dan Sinuraya, J., (2013), Pengaruh Model Pembelajaran Inquiry Training Terhadap Hasil Belajar Siswa Pada Materi Pokok Suhu Dan Pengukuran Kelas VII Semester I MTs N 2 Medan T.P 2012/2013, Jurnal INPAFI 1: 3440

Joyce, B., Weil, M., dan Calhoun, E., (2011), Models of Teaching: Model-Model Pembelajaran Edisi Kedelapan, Pustaka Pelajar, Yogyakarta.

Sirait, R., dan Sahyar, (2013), Analisis Penguasaan Konsep Awal Fisika Dan Hasil Belajar Fisika Pada Pembelajaran Menggunakan Model Inquiry Training Pada Materi Listrik Dinamis,Jurnal Online Pendidikan Fisika2: 1-8.

Sudjana, N., (2005), Metode Statistika, PT Tarsito, Bandung

Trisno, Kendek, Y., dan Pasaribu, M., (2014), Pengaruh Model Pembelajaran Training Inquiry Terhadap Hasil Belajar Pada Pokok Bahasan Kalor SiswaSMP Negeri 9 Palu, Jurnal Pendidikan Fisika Tadulako2: 14-20 